\title{
PERLINDUNGAN HUKUM TERHADAP INVESTASI ASING YANG MASUK DI PROVINSI RIAU
}

Lysa Angraini, Dosen Program studi Ilmu Hukum pada Fakultas Syari'ah dan Hukum Universitas Islam Negeri sultan syarif kasim Riau, Jl. HR. Soebrantas KM. 15 Simpang Panam, Email: Lysa.Angrayni@gmail.com Elza Umami Fitri, Bawaslu Provinsi Riau, Jl. Adi Sucipto, Komplek Transito No. 284, sidomulyo timur, marpoyan damai pekanbaru, 28215. Email: elzaumamifitri6@gmail.com

\begin{abstract}
ABSTRAK
Law number 25 year 2007 concercing Capital investment gives equal treatment to Domestic Investment and Foreign Investors with due regard to the national interest, ensures legal certainly, and security of business for investors since the process of licencing until the end of investment activities in accordance with the provisions of legislation. Under the act it is clear that foreign investors must obtain legal protection and certainly as domestic investors. But the reality is different so the impact that arises that urcertainty is the development of unstable foreign investment, a significant increase and decrease in Riau province. While the factors causing the decline of foreign investment in Riau Province are the differences in both licensing, raw materials and protection between foreign investors and domestic investors in Riau province, so foreign investors feel unsafe in Riau province.
\end{abstract}

Key words : Protection, Investation, Riau province

\section{ABSTRAK}

Undang-undang Nomor 25 Tahun 2007 tentang Penanaman Modal memberi perlakuan yang sama bagi Penanaman Modal dalam Negeri dan penanam modal asing dengan tetap memperhatikan kepentingan nasional, menjamin kepastian hukum, dan keamanan berusaha bagi 
penanam modal sejak proses pengurusan perizinan sampai dengan berakhirnya kegiatan penanaman modal sesuai dengan ketentuan peraturan perundang-undangan". Berdasarkan Undang-Undang tersebut jelaslah bahwa penanam modal asing harus mendapatkan perlindungan dan kepastian hukum sebagaimana penanam modal dalam negeri. Tetapi pada kenyataannya berbeda sehingga dampak yang timbul ketidak pastian tersebut ialah perkembangan investasi asing yang tidak stabil, adanya kenaikan dan penurunan yang sangat signifikan di Provinsi Riau. Sedangkan faktor yang menjadi penyebab penurunan investasi asing di Provinsi Riau adalah adanya perbedaan baik dalam perizinan, bahan baku, dan perlindungan antara penanam modal asing dan penanam modal dalam negeri di Provinsi Riau, sehinnga para investor asing merasa tidak aman untuk berinvestasi di Provinsi Riau.

\section{Kata kunci : Perlindungan, investasi, Provinsi Riau}

\section{PENDAHULUAN}

Indonesia adalah Negara Hukum sebagaimana telah tertuang dalam Pasal 1 ayat (3) UUD 1945 yang mengatakan bahwa, "Indonesia adalah Negara Hukum". ${ }^{1}$ Setiap negara menganut sistem pemerintahan yang sesuai dengan Falsafah Negara dan Undang-Undang Dasar yang dimilikinya dan sebagai negara hukum Indonesia mempunyai aturan yang bersifat mengikat, memaksa, dan mempunyai sanksi yang tegas dan nyata bagi pelanggarnya. Aturan tersebut diwujudkan dalam suatu wujud yang nyata dan dijunjung tinggi oleh setiap warga negara yaitu Pancasila dan UUD 1945.

Hasil perubahan UUD 1945 melahirkan bangunan kelembagaan negara yang satu sama lain dalam posisi setara dengan saling melakukan kontrol (Cheks and Balances), mewujudkan supremasi hukum dan keadilan serta menjamin dan melindungi hak asasi manusia. Kesetaraan

\footnotetext{
${ }^{1}$ UUD 1945 Pasal 3 ayat (3)
} 
dan ketersediaan saling kontrol inilah prinsip dari sebuah negara demokrasi dan negara hukum. Dengan kata lain, bahwa perubahan terhadap UUD 1945 tersebut meliputi hampir seluruh tiga kelompok materi muatan konstitusi. ${ }^{2}$

Pembukaan Undang-Undang Dasar Negara Republik Indonesia Tahun 1945 terkandung banyak amanat konstintusi yang harus dilaksanakan oleh penyelenggara negara, seperti antara lain untuk memajukan kesejahteraan umum dan mencerdaskan kehidupan bangsa. Amanat tersebut mengandung makna negara berkewajiban memenuhi kebutuhan setiap warga negara melalui sistem pemerintahan yang mendukung terciptanya penyelenggara pelayanan publik yang prima dalam rangka memenuhi kebutuhan dasar dan hak sipil setiap warga negara atas barang pubik, jasa publik dan pelayanan publik..

Penjelasan Pasal 18, Bab IV UUD 1945 menerangkan bahwa karena negara Indonesia itu adalah negara kesatuan, Indonesia tidak akan mempunyai daerah didalam lingkungannya juga berbentuk negara. Daerah Indonesia dibagi menjadi daerah Provinsi dan daerah Provinsi dibagi pula menjadi daerah yang lebih kecil. Semua menurut aturan yang ditetapkan dengan Undang-undang. Di daerah-daerah itu bersifat otonom diadakan badan perwakilan daerah karena di daerahpun pemerintah akan bersendikan dasar permusyawaratan. ${ }^{3}$ Maksudnya ialah bahwa wilayah Indonesia dibagi menjadi sejumlah daerah besar dan kecil yang bersifat otonom,yaitu daerah yang boleh mengurus rumah tangganya sendiri dan daerah administrasi,yaitu daerah yang tidak boleh berdiri sendiri.

Membentuk susunan pemerintah daerah-daerah itu, pemerintah bersama DPR telah menetapkan Undang-undang No.5 Tahun 1974 tentang Pokok-Pokok Pemerintahan di Daerah, yang dilaksanakan dengan Intruksi Menteri Dalam Negeri No. 26 Tahun 1974. Undang-

${ }^{2}$ Jimly Asshiddiqie, Format Kelembagaan Negara dan Pergeseran Kekuasaan dalam UUD 1945, (Yogyakarta, 2004), hlm. 11

${ }^{3}$ C.S.T Kansil dan Christine S.T Kansil, Sistem Pemerintahan Indonesia, (Jakarta: PT Bumi Aksara.2003),hlm. 141 
undang itu mengatur pokok-pokok penyelenggaraan pemerintahan daerah otonom dan pokok-pokok penyelenggaraan pemerintahan yang menjadi tugas pemerintahan pusat di daerah. Selain itu, diatur juga pokok-pokok penyelenggaraan urusan pemerintahan berdasarkan asas desentralisasi, dekonsentralisasi, dan tugas perbantuan.

Undang-undang Nomor 1 Tahun 1967 tentang Penanaman Modal Asing jo Undang-undang Nomor 11 Tahun 1970 tentang Perubahan dan Tambahan Undang-undang Nomor 1 tahun 1967 tentang Penanaman Modal Asing dan Undang-undang Nomor 6 tahun1968 tentang Penanaman Modal Dalam Negeri jo Undang-undang Nomor 12 tahun 1970 tentang Perubahan dan Tambahan Undang-undang Nomor 6 tahun 1968 tentang Penanaman Modal dalam Negeri dinyatakan tidak berlaku lagi dan telah dicabut dengan Undang-undang Nomor 25 tahun 2007 tentang Penanaman Modal. Dengan demikian, bahwa yang menjadi payung dari penanaman modal investasi di Indonesia saat ini adalah Pasal 1 Undang-undang Nomor 25 Tahun 2007 tentang Penanaman Modal. "Penanaman modal adalah segala sesuatu atau bentuk kegiatan penanaman modal, baik oleh penanaman modal dalam negara maupun dari asing untuk melakukan usaha diwilayah negara RepublikIndonesia".

Undang-undang ini terdiri dari $14 \mathrm{Bab}$ dan 40 pasal. Hal-hal yang diatur dalam Undang-undang Nomor 25 tahun 2007 tentang Penanaman Modal. ${ }^{4}$ Satu hal yang ingin dikemukakan disini, suka atau tidak di era masa kini yang sering juga disebut sebagai era globalisasi, berbagai negara yang selama bertahun-tahun menutup diri terhadap dunia luar, telah membuka diri secara terbuka. Demikian juga halnya, arus pergerakan modal pun begitu cepat, sehingga dimana ada peluang disitulah ia berhenti. Hal ini tentu menjadi menarik, peluang yang didapat oleh investor, karena diberikan atau diciptakan oleh penerima modal ataukah adanya sebab lain. Tampaknya dua-duanya yakni baik penerima

\footnotetext{
hlm.77

${ }^{4}$ Salim, Sutrisno Budi, Hukum Investasi Indonesia, (Jakarta; Raja Grafindo Persada, 2012,
} 
modal maupun penanaman modal saling membutuhkan. Seperti diketahui, pemodal atau investor yang hendak menanamkan modal pada umumnya berasal dari negara-negara maju.

Disinilah aturan hukum mulai berperan, apakah norma-norma berinvestasi sudah memenuhi standar dalam lalu lintas pergaulan internasional atau belum, maka Indonesia sebagai salah satu anggota komunitas masyarakat internasional, sangat perlu menyesuaikan aturan investasinya yang sudah berjalan selama 40 tahun lebih, tepatnya pada akhir April tahun 2007 yang lalu pemerintah menerbitkan Undang-undang Penanaman Modal.

Penanaman modal merupakan segala kegiatan menanamkan modal, baik oleh penanam modal dalam negeri maupun penanam modal asing untuk melakukan usaha di wilayah negara RepublikIndonesia, Indonesia sebagai negara kepulauan yang memiliki sumber daya alam melimpah dari pertanian, peternakan, perikanan, kehutanan, maupun pertambangan, tidak serta merta sumber daya alam melimpah, dapat diambil dengan sendirinya atau diolah, perlu dibangun infrastruktur sarana prasarana dalam mengolahnya oleh negara Indonesia melalui pemerintah, oleh karena itu timbulnya keinginan untuk menarik investor, yang dimulai sejak zaman orde baru hingga sekarang, tetapi pada pertengahan tahun 1997 Indonesia mengalami krisis moneter. ${ }^{5}$

Dengan masuknya investor asing dalam kegiatan investasi di Indonesia dimaksudkan sebagai pelengkap untuk mengisi sektor-sektor usaha dan industri yang dapat dilaksanakan sepenuhnya, baik karena alasan teknologi, manajemen, maupun alasan permodalan. Modal asing juga diharapkan secara langsung dapat mempercepat proses pembangunan ekonomi di Indonesia.

Maka dari itu dapat dimaklumi mengapa investor membutuhkan adanya perlindungan hukum yang jelas dan tidak berubah-rubah, sebab

${ }^{5}$ Efri Naldi, Perkembangan Investasi Asing pada Era Otonomi Daerah di Profinsi Riau, Skripsi, hlm. 23 
dalam melakukan investasi selain tunduk kepada ketentuan hukum investasi, juga ada ketentuan lain yang terkait dan tidak bisa dilepaskan begitu saja. Ketentuan tersebut antara lain berkaitan dengan perpajakan, ketenagakerjaan, dan masalah pertanahan. Semua ketentuan ini akan menjadi pertimbangan bagi investor dalam melakukan investasi, supaya kegiatan investasi bisa berjalan dengan baik dan adil. ${ }^{6}$

Sumber pembiayaan melalui penanaman modal asing langsung ini merupakan sumber pembiayaan luar negeri yang paling potensial dibandingkan dengan sumber yang lain, karena Penanaman Modal Asing langsung lebih penting dalam menjamin kelangsungan pembangunan.Dengan datangnya Penanaman Modal Asing juga diharapkan secara langsung maupun tidak langsung dapat lebih merangsang iklim atau kehidupan dunia usaha dalam berbagai bidang usaha, serta dapat dimanfaatkan dalam upaya menembus jaringan pemasaran internasional melalui jaringan yang mereka miliki.

Dengan adanya kebutuhan suatu negara terhadap penanaman modal asing untuk mengembangkan perekonomian yang diharapkan akan membawa pada kesejahteraan dan setelah melihat perkembangan modal asing yang sangat tidak menentu disebagian negara, maka perlu dikaji dan faktor-faktor yang dapat mempengaruhi penanaman modal asing agar investasi dalam bentuk penanaman

Berdasarkan uraian tersebut diatas penulis merasa tertarik untuk mengadakan penelitian dengan judul "Perlindungan Hukum Terhadap Investasi Asing di Provinsi Riau".

\section{TINJAUAN PUSTAKA}

Perlindungan hukum adalah tindakan atau upaya untuk melindungi masyarakat dari perbuatan sewenang-wenang oleh penguasa yang tidak sesuai dengan aturan hukum, untuk mewujudkan ketertiban dan 
ketentraman sehingga memungkinkan manusia untuk menikmati martabatnya sebagai manusia. ${ }^{7}$

Perlindungan hukum dapat dibedakan menjadi dua :

1. Perlindungan Hukum Preventif

Perlindungan yang diberikan oleh pemerintah dengan tujuan untuk mencegah sebelum terjadinya pelanggaran. Hal ini terdapat dalam peraturan perundang-undangan dengan maksud untuk mencegah suatu pelanggaran serta memberikan ramburambu atau batasan-batasan dalam melakukan suatu kewajiban.

2. Perlindungan Hukum Refresif

Perlindungan hukum refresif merupakan perlindungan akhir berupa sanksi, denda, penjara, dan hukuman tambahan yang diberikan apabila sudah terjadi sengketa atau telah dilakukan suatu pelanggaran. ${ }^{8}$

Aturan hukum baik berupa Undang-undang maupun hukum tidak tertulis, dengan demikian, berisi aturan-aturan yang bersifat umum yang menjadi pedoman bagi individu bertingkah laku dalam hidup bermasyarakat, baik dalam hubungan dengan sesama maupun dalam hubungannya dengan masyarakat. Aturan-aturan itu menjadi batasan bagi masyarakat dalam membebani atau melakukan tindakan terhadap individu. Adanya aturan seperti itu dan pelaksanaan aturan tersebut menimbulkan kepastian hukum. Dengan demikian, kepastian hukum mengandung dua pengertian, yaitu pertama, adanya aturan yang bersifat umum membuat individu mengetahui perbuatan apa yang boleh atau tidak boleh dilakukan dan yang kedua, berupa keamanan hukum bagi individu dari kesewenangan pemerintah karena dengan adanya aturan yang

${ }^{7}$ Setiono, Rule of Law Supremasi Hukum, (Surakarta; Magister IImu Hukum Program Pascasarjana Universitas Sebelas Maret. 2004) hlm. 3

${ }^{8} \mathrm{Ibid}, \mathrm{hlm} .20$ 
bersifat umum itu individu dapat mengetahui apasaja yang boleh dibebankan atau dilakukan oleh negara terhadap individu. ${ }^{9}$

Investasi atau penanaman modal merupakan istilah yang dikenal dalam kegiatan bisnis sehari-hari maupun dalam bahasa perundangundangan. Istilah investasi merupakan istilah yang populer dalam dunia usaha, sedangkan istilah penanaman modal lazim digunakan dalam perundang-undangan. Namun pada dasarnya kedua istilah tersebut mempunyai pengertian yang sama. ${ }^{10}$

Pada dasarnya setiap badan usaha yang menghasilkan suatu produk dengan atau tanpa melihat skala usahanya senantiasa akan terikat dengan kebutuhan investasi baik untuk tujuan meningkatkan skala produksinya, memperbaiki efisiensi operasinya melalui kebijakan peremajaan alat-alat produksinya maupun dengan tujuan untuk mengadakan alat produksi baru guna memperluas produk yang dihasilkannya. ${ }^{11}$

Ada beberapa alasan mengapa seseorang melakukan investasi, antara lain adalah:

1. Untuk medapatkan kehidupan yang lebih layak dimasa yang akan datang. Seseorang yang bijaksana akan berfikir bagaimana meningkatkan taraf hidupnya dari waktu kewaktu atau setidaktidaknya bagaimana berusaha untuk mempertahankan tingkat pendapatannya yang ada sekarang agar tidak berkurang dimasa yang akan datang.

2. Mengurangi tekanan inflasi dengan melakukaan investasi dalam pemilihan perusahaan atau obyek lain, seseorang dapat

\footnotetext{
${ }^{9}$ Peter Mahmud Marzuki, Pengantar Ilmu Hukum. (Jakarta; Kencana 2008), hlm. $157-159$

${ }_{10}$ Ida Bagus Rachmdi Supancana, Kerangka Hukum dan Kebijakan Investasi Langsung di Indonesia, (Jakarta: Ghia Indonesia, 2006), hlm. 1.

${ }_{11}$ Salim Basamalah, dkk, Penilaian Kelayakan Rencana Penanaman Modal, Sebuah Studi Proyek Bermotif Laba, Fakultas Ekonomi Universitas Muslim Indonesia, Ujung Pandang, Universitas Gadjah Mada, Yogyakarta, 1994, hlm. 1
} 
menghindarkan diri agar kekayaan atau harta miliknya tidak merosot nilainya karena digerogoti oleh inflasi.

3. Dorongan untuk menghemat pajak, beberapa negara didunia banyak melakukan kebijakan yang bersifat mendorong tumbuhnya investasi dimasyarakat yang melakukan investasi pada bidang-bidang usaha tertentu. ${ }^{12}$

Lincolin Arsyad mengemukakan setidaknya ada 3 manfaat yang dapat diraih denganmasuknya investasi: ${ }^{13}$

1. Perluasan kesempatan kerja

Bukti empiris menunjukkan bahwa perluasan kesempatan kerja yang yang dihasilkan oleh adanya investasi meyakinkan karena satu hal dan hal lain. Pengamat dengan yakinnya mengatakan bahwa penggeseran terhadap perusahaan-perusahaan lokal oleh perusahaan-perusahaan multinasional akan menambah lapangan kerja setempat.

2. Alih Teknologi

Manfaat pokok kedua yang diharapkan dari investasi asing adalah proses alih teknologi, keterampilan, dan know how. Oleh karena banyak riset lapangan dan kegiatan-kegiatan pembangunan dilakukan oleh perusahaan-perusahaan di Amerika Utara, Eropa dan Jepang, maka perusahaan tersebut sangat potensial sebagai sumber yang kaya akan informasi yang bernilai tentang teknologi, proses, metode pemasaran dan pendekatan-pendekatan manajerial yang baru, jika informasi ini dapat dicangkokkan ke negara-negara tuan rumah maka kenaikan pertumbuhan dan produktifitas yang dihasilkan akan cukup berarti dalam jangka panjang.

\section{Manfaat Perolehan Devisa}

${ }^{12}$ Kamaruddin Ahmad, Dasar-dasar Manajemen Investasi, (Rineka Cipta, 1996) hlm 3-4

${ }^{13}$ Lincolin Arsyad, Ekonomi pembangunan, (Yogyakarta; STIE YKPN, 1999), Edisi IV hIm. 179-181 
Manfaat ketiga dari investasi adalah untuk memperoleh tabungan dan mendapatkan cadangan devisa.

Faktor-faktor tersebut terjadi bersamaan atau muncul dari salah satu saja, dan risiko yang dimaksud antara lain: ${ }^{14}$

1. Risiko tingkat bunga, terutama jika terjadi kenaikan

2. Risiko daya beli, disebabkan inflasi

3. Risiko pasar besar dan bull, trend pasar turun atau naik

4. Risiko manajemen, kesalahan/kekeliruan dalam pengelolaan

5. Risiko kegagalan, keungan perusahaan kearah kepailitan

6. Risiko likuiditas, kesulitan pencairan/pelepasan aktiva

7. Risiko penarikan, kemungkinan pembelian kembali aset/surat berharga oleh emiten

8. Risiko konversi, keharusan penukaran suatu aktiva

9. Risiko politik, baik nasional maupun internasional

10. Risiko industri, munculnya saingan produk homogen

Undang-Undang Nomor 25 Tahun 2007 tentang Penanaman Modal memberikan kemudahan kepada penanam modal yang bertujuan menarik penanam modal baik penanam modal asing ataupun penanam modal dalam negeri, untuk melakukan usaha di wilayah Republik Indonesia. Dan pemberian kemudahan penanaman modal dalam bentuk percepatan pemberian perizinan sebagaimana dimaksud pada pasal 3 ayat 2 diselenggarakan melalui pelayanan terpadu satu pintu sesuaiketentuan peraturan perUndang-undangan yang berlaku. ${ }^{15}$

Proses investasi meliputi pemahaman dasar-dasar keputusan investasi dan bagaimana mengorganisir aktifitas-aktifitas dalam proses keputusan investasi. Hal mendasar dalam proses keputusan investasi adalah pemahaman hubungan antara return yang diharapkan dari

${ }^{14}$ Mardiasmo, Analisis Investasi dan manajemen Portofolio, (Yogyakarta; STIE YKPN, 1999) hlm. 3

${ }_{15}$ Peraturan Pemerintah No.45 Tahun 2008 tentang Pedoman Insentif dan Pemberian Kemudahan Penanaman Modal di Daerah 
suatu investasi merupakan hubungan yang searah dan linear ${ }^{16}$ artinya semakin besar risiko yang harus ditanggung, semakin besar pula tingkat return yang diharapkan. Hubungan inilah yang menjawab pertanyaan mengapa tidak semua investor hanya berinvestasi pada aset yang menawarkan tingkat return yang paling tinggi. Disamping memperhatikan return yang tinggi, investor juga harus mempertimbangkan tingkat risiko yang harus ditanggung. ${ }^{17}$

\section{PEMBAHASAN}

\section{Perlindungan Hukum Terhadap Investasi Asing Yang Masuk Di Provinsi Riau}

Undang-undang Nomor 25 Tahun 2007 tentang Penanaman Modal bahwa: "Memberi perlakuan yang sama bagi penanam modal dalam negeri dan penanam modal asing dengan tetap memperhatikan kepentingan Nasional. Menjamin kepastian hukum, kepastian berusaha, dan keamanan berusaha bagi penanam modal sejak proses pengurusan perizinan sampai dengan berakhirnya kegiatan penanaman modal sesuai dengan ketentuan peraturan perundangundangan". ${ }^{18}$ Dampak dari ketidakpastian tersebut mengakibatkan perkembangan investasi asing di Provinsi Riau mengalami kenaikan dan penurunan yang sangat signifikan.

Hal ini disebabkan karena tidaklah sesuai dengan apa yang disebutkan di dalam Undang-undang tersebut. Dengan adanya Undang-undang Nomor 25 Tahun 2007 Tentang Penanaman Modal terlihat jelas bahwa terjadinya kenaikan dan penurunan jumlah investasi asing di Provinsi Riau disebabkan oleh faktor-faktor yang

${ }^{16}$ Edurdus Tandelin, Analisa Investasi dan manajemen Portofolio, (Yogyakarta; BPFE 2001), hlm. 5

${ }_{17}$ Istilah return dalam investasi adalah tingkat keuntungan yang akan diperoleh investor dari modal yang diinvestasikannya. Semakin tinggi tingkat risiko investasi maka semakin tinggi return yang mungkin akan diperoleh dari investasi.

${ }^{18}$ Undang-undang Nomor 25 Tahun 2007 tentang Penanaman modal 
membuat para investor merasa tidak nyaman untuk berinvestasi di Provinsi Riau, yaitu faktor hukum dan faktor politik.

Mengingat iklim politik yang tidak stabil dan tidak menentu, terbukti mempengaruhi penanaman modal dengan kenaikan dan penurunan jumlah investasi asing yang tidak stabil dari tahun ke tahun, tentunya investor asing akan mencari tempat untuk menanamkan modalnya pada suatu negara yang memiliki iklim usaha yang kondusif serta faktor hukum yang berkaitan erat dengan perlindungan hukum yang diberikan suatu negara bagi kegiatan penanaman modal asing. Tidak hanya langsung bagi kegiatan penanam modal asing, namun faktor hukum juga merupakan penunjang adanya kondisi politik dan ekonomi yang sehat bagi penanam modal Asing. Melalui sistem hukum yang dapat memberikan perlindungan, akan tercipta kepastian, keadilan, dan efisiensi bagi penanam modal asing. ${ }^{19}$

Sebagaimana ungkapan yang disampaikan oleh Yusub, bahwa investasi asing sangat berperan penting dalam meningkatkan pertumbuhan ekonomi, tetapi pada saat ini perkembangan investasi asing di Provinsi Riau tidaklah stabil, itu semua disebabkan oleh banyak hal yang harus dipertimbangkan oleh investor saat ingin menanamkan modal.

Kendala-kendala yang terjadi saat ingin berinvestasi, seperti permasalahan pada perizinan, terkadang apabila izin telah selesai terjadi kendala terhadap sulitnya memperoleh bahan baku, sehingga para investor tersebut merasa bahwa Provinsi Riau tidaklah aman untuk berinvestasi, padahal kami telah berusaha memberikan kemudahan-kemudahan serta pelayanan yang maksimal agar mereka kembali tertarik untuk berinvestasi di Provinsi Riau. Namun usaha yang dilakukan tersebut bukan semudah apa yang diungkapkan tentunya perlu kesabaran dan dengan langkah-langkah yang telah ditentukan.

${ }^{19}$ Dhaniswara K, Harjono Pemahaman Hukum Bisnis bagi pengusaha, (Jakarta;PT Raja Grafindo Persada), 2017, hlm.89 
Pada saat ini para penanam modal asing masih saja ragu untuk berinvestasi di Provinsi Riau, hal itu disebabkan oleh kebijakankebijakan yang sering tumpang tindih atau tidak konsisten dan kepastian hukum di Indonesia ini kurang bersahabat.

\section{Tabel 1}

Perbandingan Realisasi Investasi PMA Secara Keseluruhan di Provinsi Riau Tahun 2015-2017

\begin{tabular}{|l|l|l|}
\hline NO & \multicolumn{1}{|c|}{ TAHUN } & $\begin{array}{c}\text { JUMLAH INVESTASI } \\
\text { (Juta US \$) }\end{array}$ \\
\hline 1 & 2015 & US \$ 1.369,56 \\
\hline 2 & 2016 & US \$ 653,39 \\
\hline 3 & 2017 & US \$ 869,10 \\
\hline
\end{tabular}

Pada tabel diatas jelas terlihat perkembangan investasi asing yang tidak stabil dari tiga tahun terakhir, pada tahun 2015 jumlah investasi asing meningkat yaitu US \$1.369,56 dan pada tahun 2016 mengalami penurunan US \$653,39, sedangkan pada tahun 2017 hanya mengalami kenaikan yang tidak sebanding dengan penurunan yang terjadi sebelumnya yaitu US \$ 869,10.

Perusahaan Asing yang ada di Provinsi Riau, bahwa permasalahan utama yang menjadi kendala bagi investor untuk menanamkan modalnya di suatu negara khususnya Indonesia adalah kepastian hukum dan kestabilan politik di negara tersebut, serta proses perizinan yang berbelit-belit dan panjang diikuti oleh biaya yang tidak transparan, karena investor dalam menanamkan modalnya menghitung risiko. 


\section{Langkah Yang Dilakukan Oleh Pemerintah Dalam Menciptakan Perlindungan Hukum Pada Investasi Asing di Provinsi Riau}

Strategi untuk mendorong kegiatan investasi didaerah pada dasarnya bukan hanya tanggung jawab dari pemerintah daerah, namun sekaligus juga tanggung jawab dari pemerintah pusat. Konsepsi ini timbul didasarkan pada suatu pemahaman berdasarkan pada konsep negara kesatuan, oleh karena itu adanya visi dan misi yang sinkron antara pemerintah pusat dan daerah dengan tetap mengedepankan kesejahteraan masyarakat secara keseluruhan hendaknya menjadi dasar pijakan pokok dalam merealisasikan kebijakan dalam bidang investasi. ${ }^{20}$

Langkah-langkah yang dilakukan oleh pemerintah terhadap penanaman modal atau investasi di Provinsi Riau, mencakup diantaranya adalah:

1. Menyederhanakan proses dan tata cara perizinan dan persetujuan dalam rangka penanaman modal

2. Menawarkan berbagai insentif dibidang perpajakan dan non perpajakan

3. Menyempurnakan berbagai produk hukum dengan mrnjamin iklim investasi yang sehat dan kondusif

4. Menyempurnakan tugas, fungsi dan wewenang instansi terkait untuk dapat memberikan pelayanan yang lebih baik.

Menarik investor ke daerah perlu menggunakan beberapa strategi yaitu dengan cara menilai kekuatan dari daerah dengan mengidentifikasi ketersediaan komoditi yang berdaya saing, potensial market, kemudahan akses, saluran distribusi serta keterampilan tenaga kerja. Menyiapkan paket insentif, menyiapkan infrastruktur yang mendukung seperti fasilitas jalan, air bersih, listrik da sebagainya Dan pemerintah akan terus berusaha memberikan yang terbaik untuk para

${ }^{20}$ Suhendro, Hukum Investasi di Era Otonomi Daerah, Gitanagari, Yogyakarta, 2005, hlm.65 
investor, baik itu penanam modal asing ataupun penanam modal dalam Negeri.

Menyadari pentingnya investasi asing di Provinsi Riau, pemerintah Provinsi Riau harus menciptakan suatu iklim investasi yang mampu memberikan kenyamanan dan keamanan kepada para investor dengan mengeluarkan aturan-aturan tentang penanam modal asing dan kebijaksanaan-kebijaksanaan pemerintah, yang pada dasarnya tidak merugikan kepentingan Nasional dan kepentingan Invesor.

1. Akan membuat berbagai peraturan daerah yang menjamin perlindungan dan kepastian hukum terhadap investasi asing yang masuk ke daerah dan bukan membuat peraturan daerah yang justru menciptakan hambatan investasi. Dan implikasi yang dibuat secara alamiah akan menjamin adanya suatu perlindungan bagi investasi asing.

2. Membuat peraturan daerah yang konsisten satu sama lainnya serta kebijakan yang tidak berubah-rubah dan berbeda-beda terhadap hal pokok yang sama

3. Membuat peraturan daerah yang memberikan kemudahan bagi dunia usaha untuk melakukan kegiatan usaha serta peraturan daerah yang fleksibel terhadap masuknya dunia usaha ke Provinsi Riau

4. Serta akan menjamin adanya penegakan hukum yang tegas dan transparan. Sehingga perusahaan-perusahaan asing yang yang telah ada maupun yang akan melakukan investasi di Provinsi Riau tidak akan di peras oleh oknum-oknum pemerintah daerah dan DPRD melalui kutipan tidak resmi.

Peranan pemerintah daerah saja tidak cukup dalam menjamin adanya kepastian hukum demi mewujudkan perlindungan hukum terhadap investasi asing, haruslah di barengi oleh peranan pemerintah 
pusat, sehinga akan menunjang masuknya investasi asing ke suatu daerah.

\section{KESIMPULAN}

Dari penjelasan di atas dapat disimpulkan sebagai berikut:

1. Berdasarkan data yang dikeluarkan dari Badan Penanaman Modal dan Promosi Daerah Provinsi Riau menunjukkan perkembangan investasi asing di Provinsi Riau mengalami kenaikan dan penurunan yang sangat siknifikan. Hal ini di sebabkan karena perlindungan hukum terhadap penanam modal asing sangat kurang diperhatikan baik itu melalui kebijakankebijakan Pemerintah Daerah atau dari segi keamanan sehingga investor asing harus berhati-hati dan memikir dua kali apabila ingin menanamkan modalnya di Provinsi Riau.

2. Banyaknya Kendala dalam penanaman modal di ProvinsiRiau yaitu masalah jalur birokrasi, yang terkesan terlalu berbelit-belit serta tidak adanya transparansi dan kepastian hukum bagi calon investor karena aspek resiko dari menanam modal yang sangat diperhatikan oleh para investor adalah aspek stabilitas politik dan keamanan. 


\section{DAFTAR PUSTAKA}

Jimly Asshiddiqie, Format Kelembagaan Negara dan Pergeseran Kekuasaan dalam UUD 1945, Yogyakarta, 2004

C.S.T Kansil dan Christine S.T Kansil,Sistem Pemerintahan Indonesia, Jakarta: PT Bumi Aksara, 2003

Salim, Sutrisno Budi, Hukum Investasi Indonesia, Jakarta; Raja Grafindo Persada, 2012

Efri Naldi, Perkembangan Investasi Asing pada Era Otonomi Daerah di Profinsi Riau, Skripsi

Setiono, Rule of Law Supremasi Hukum, Surakarta; Magister IImu Hukum Program Pascasarjana Universitas Sebelas Maret, 2004

Peter Mahmud Marzuki, Pengantar IImu Hukum, Jakarta; Kencana, 2008

Ida Bagus Rachmdi Supancana, Kerangka Hukum dan Kebijakan Investasi Langsung di Indonesia, Jakarta: Ghia Indonesia, 2006

Salim Basamalah, dkk, Penilaian Kelayakan Rencana Penanaman Modal, Sebuah Studi Proyek Bermotif Laba, Fakultas Ekonomi Universitas Muslim Indonesia, Ujung Pandang, Universitas Gadjah Mada, Yogyakarta, 1994

Kamaruddin Ahmad, Dasar-dasar Manajemen Investasi, Jakarta; Rineka Cipta, 1996

Lincolin Arsyad, Ekonomi pembangunan, Yogyakarta; STIE YKPN, 1999

Mardiasmo, Analisis Investasi dan manajemen Portofolio, Yogyakarta; STIE YKPN, 1999

Peraturan Pemerintah No.45 Tahun 2008 tentang Pedoman Insentif dan Pemberian Kemudahan Penanaman Modal di Daerah

Edurdus Tandelin, Analisa Investasi dan manajemen Portofolio, Yogyakarta; BPFE 2001

Istilah return dalam investasi adalah tingkat keuntungan yang akan diperoleh investor dari modal yang diinvestasikannya. Semakin tinggi tingkat risiko investasi maka semakin tinggi return yang mungkin akan diperoleh dari investasi.

Dhaniswara K, Harjono Pemahaman Hukum Bisnis bagi pengusaha, Jakarta;PT Raja Grafindo Persada

Suhendro, Hukum Investasi di Era Otonomi Daerah, Gitanagari, Yogyakarta, 2005

Undang-undang Dasar Republik Indonesia 1945

Undang-undang Nomor 25 Tahun 2007 tentang Penanaman modal 